\title{
CONSUMER SWITCHING BEHAVIOR IN BANKING INDUSTRY: CAN CONSUMER BASE BE PURCHASED, OR EARNED?
}

\author{
Mehmet Özer DEMiR ${ }^{1}$
}

Zuhal GÖK DEMiR²

\begin{abstract}
Loyalty membership programs are widely used as a strategical tool in banking. In the paper a unique loyalty membership program in Turkey in which consumers are offered cash in order to convince them to switch their financial service provider, bank, is studied. Literature supports evidence for relationships between switching barriers and intention to switch, however literature lacks studies testing the assumptions of theories on consumer loyalty in specific industries. Exploratory in nature, the study tests the literature supported relationships based on a real life case. The paper aims to enligthen whether the consumers' loyalty can be bougth with cash and other provided benefits to make customers switch their current service provider into new account after a special loyalty membership program offered for an organization's employees. The purpose of the paper is to research effects of switching barriers on intention to switch in order to understand whether consumer base can be purchased, or consumers are earned. Structural Equation Modeling is performed with the data collected from a survey of 212 employees of an organization. The results suggest that, in banking sector, imitable switching barriers are not useful against switching intentions.
\end{abstract}

Keywords: Switching Barriers, SEM, Banking, Loyalty Membership Programs

JEL Classification: M31, G21

\section{BANKACILIK SEKTÖRÜNDE TÜKETICi DEĞIŞTiRME DAVRANIŞI: TÜKETICi TABANI SATINALINABILIR MI YOKSA KAZANILIR MI?}

\section{Öz}

Sık kullanıcı programları bankacılık sektöründe yaygın olarak kullanılan stratejik bir araçtır. Çalışmada tüketicilerin mevcut finansal hizmet sağlayıcıları bankayı değiştirmelerine ikna emek amacıyla nakit paranın teklif edildiği Türkiye'ye özel bir sık kullanıcı programı incelenmiştir. Yazında değiştirme engelleri ile değiştirme niyeti arasında ilişki olduğu belirtilmiştir, ancak bu ilişkiler sektör spesifik olarak test edilmemiştir. Keşfedici araştırma yapısında tasarlanan çalışmada literatür tarafından önerilen ilişkiler gerçek hayat vakası üzerinden test edilmiştir. Çalışmanın amacı tüketicilerin sadakatinin nakit para ve tüketicilere sunulan diğer faydalar ile satın alınıp alınamayacağını, bir örgütün çalışanlarına teklif edilen belirli bir sık kullanıcı programı sonrası tüketicilerin mevcut hizmet sağlayıcılarını değiştirip yeni bir hesap açıp açmayacaklarını aydınlatmaya çalışmaktır. Araştırmada tüketici değiştirme engellerinin değitirme niyeti üzerindeki etkisini inceleyerek tüketici sadakatinin satın mı alındığı yoksa kazanıldığı mı incelenmiştir. Yapısal eşitlik modellemesi kullanılarak 212 katılımcının yer aldığı veriler incelenmiştir. Araştırma bulguları bankacılık sektöründe taklit edilebilir değiştirme engellerinin değiştirme niyetini sağlamakta kullanışıı olmadığını göstermektedir.

Anahtar Kelimeler: Değiştirme Engelleri, SEM, Bankacılık, Sık Kullanıcı Programları JEL SInıflandırması: M31, G21

\footnotetext{
${ }^{1}$ Dr. Öğr. Üyesi, Alanya Alaaddin Keykubat Üniversitesi, Mühendislik Fakültesi, İşletme Mühendisliği Bölümü, mehmet.demir@alanya.edu.tr, ORCID:0000-0002-5035-0530

${ }^{2}$ Dr. Öğr. Üyesi, Alanya Alaaddin Keykubat Üniversitesi, İsletme Fakültesi, Insan Kaynakları Bölümü,

zuhal.demir@alanya.edu.tr, ORCID:0000-0001-6489-3125
} 


\section{Introduction}

There is a concensus that market share is proportional with the profitability, that is, higher the market share more profitable the firm is. A firm with smaller market share has fewer consumers and these consumers tends to buy less than firm with bigger market share, this concept is called double jeopardy (Ehrenberg, Goodhardt, and Barwise, 1990). The relationship between market share and profitability forces companies to seek new customers in order to increase their market share, as in banking industry. Therefore, in banking sector, acquiring new customers is the centre for all bank marketing activities. Banks have to acquire new customers because customer acquisition is found to be much more important than customer defection in explaining changes in market share. Authors suggest that managers should aim to eliminate defections, at best avoiding defections is not necessary for brand growth and, at worst is not even possible (Riebe, Wright et al. 2014). How banks can actually increase their market share is somewhat problematic because all the banks offer the same or somewhat similar products and services to their customers. Also, adding new customers to their market share is becoming more and more difficult for the banks because most consumers already have a bank they are working with.

So, in order to overcome this problem Loyalty Membership Program (LMP) are considered as one of the most useful strategies for preserving market share, while running after new customers. Depending on the bank's strategy, the bank can offer different LMPs for different customer segments, or a general LMP for all of its customers. Whatever the strategy is, the aim of LMPs is to obtain repeated purchases in more profitable customer segments, thus, offenly LMPs target heavy users. The advocates of LMPs claim that increased consumer loyalty affects financial performance in the long run (Reichheld and Sasser 1990; Anderson, Fornell et al. 1994). Meanwhile, some other authors have researched whether LMPs are usefull tools for consumer loyalty, or consumer loyalty is determined by any other reasons (Capizzi and Ferguson 2005). Advocates of LMPs argue that it is not only the LMP itself but the duration and intensity of the relationship is also important (Bolton, Kannan et al. 2000). Parker and Worthington (2000) stated that whenever a bank customer feels that the LMP with the current financial service provider (FSP) is equal or the competing FSP's offer is higher, loyalty is negatively affected with the current FSP. Authors stated that fairness is one of the most important factors in long-run relationships as in customer loyalty (Olsen and Johnson 2003).

Whether the LMPs really increase the duration of customer-FSP relationships and usage levels of products/services or not is a critical question for the banks because they have to calculate the cost of LMP and the generated income through the LMP. Although implementation costs of LMP is higher than the revenues, any bank may still use LMPs because increase in market share is supposed to increase profitability in the long run. In order to increase loyalty, banks can use LMPs as a switching barrier. The aim of the switching barriers is to promote loyalty and heavy usage of products and services offered, while discouraging consumer switching behavior (CSB). CSB is defined as the level of proness to change current service provider to another service provider operating in the same industry.

Because of the fact that financial services offered are standart, mostly defined with the laws, and easy to imitate, banks heavily rely on sales promotion to gain new customers. To increase their market shares and service/card usage by existing customers, banks in Turkey offer attractive rewards programs. One of them is called "Salary Promotion". According to Turkish legal regulations, organizations have to make an agreement with a bank which employee salaries have to be paid using the bank. Agreement is open to competition, and banks "bid" for the salary agreement. There is freedom to make an agreement whose duration, number of the employees, salary amount, the amount and duration of the money that has to be hold on the account are all considered. Generally, account maintenance fee, minimum balance fee, EFT fee, money order fee etc. are not applied to salary accounts. Moreover, a certain amount of cash is paid to the employees once in an agreement period. The total amount is subject to change based on 
agreement with the bank. In another word, banks in Turkey can buy customer base with cash in order to increase their market share. Cash offered to the consumers to switch their current service provider offers a case unique for Turkey to research the CSB.

It could be stated that lots of researchers have paid attention to the realationships between switching barriers, switching behavior, consumer satisfaction, consumer involvement and loyalty (Table 1). However, fewer studies tested the assumptions of theories on consumer loyalty against switching behavior in actual real life case. Therefore, the purpose of this paper is to fill the existing gap in the literature by providing a better understanding about what factors effect CSB in actual real life case. Literature supports evidence that Costs of lost performance (COLP), Learning costs (LEAC), Sunk costs (SUNC), Setup cost/Switching cost (SETC), Special treatment benefits (STB), Financial bonds (FINB), Social bonds (SOCB), Structural bonds (STRB), Involvement (INVO), Propensity for Switching (PRFS), Satisfaction (SATI) effect Intention to stay loyal (ITSL). However, effectiveness of these variables in the case of cash offered to consumers to switch service provider is not tested. With this regard, by applying structural Equation Modelling, whether data collected fits the conceptual model is tested. In other words, literature supported theoretical relationships are tested for the data set collected. Thus, the study is designed in order to test the literature supported consumer switching variables effects on intention to change current service provider (or stay loyal). So, the paper aims to research whether the offered cash and other provided benefits make customers tend to switch their current bank into new account after a special LMP is offered for an organization's employees. In other words, the paper intends to study whether the cash offered is sufficient enough to overcome the switching barriers offered by the current FSP. Thus consumer switching behavior is researched with switching barriers (Costs of Lost Performance, Learning Costs, Sunk Costs, Setup Cost/Switching Cost, Special Treatment Benefits, Financial Bonds, Social Bonds, Structural Bonds) are considered as independent variables, involvement, propensity for switching, satisfaction and intention to stay loyal are considered as dependent variables.

The paper is presented as follows;

A special loyalty membership program (LMP) used as a marketing tool is discussed in section two.

In section three, literature review on consumer switching behavior and variables researched by the previous researchers are discussed.

Section four presents the methodology, data collection and analysis conducted.

Section find discusses the findings, managerial implications, limits of the study and the future study suggestions.

\section{Theoretical Framework}

Consumer switching behavior is widely researched with various titles (Table 1). Literature review reveals that while some researchers use the same concept for different definitions, others tend to use different concepts for different definitions.

For instance, social bonds and non-monetary switching cost are similar in definition whereas the authors prefer different namings. For example costs of lost performance is named as continuity costs by (Chebat et al., 2011), economic risk costs by (Burnham et al., 2003), risk perceptions by (Paul G. Patterson and Smith, 2003), costs of lost performance and uncertainty costs by (M. A. Jones et al., 2002), although dimension items measure the same concept. Inspection of items for CSB variables reveals that, although they are classified under different dimension names, they are thought to measure the same concepts which can be classified under 8 dimensions. So in this paper switching barriers are classified under 8 dimensions; costs of lost performance, learning costs, sunk costs, setup costs/switching costs, special treatment benefits, financial bonds, social bonds, and structural bonds. 
Table 1: Variables on Switching Barriers

\begin{tabular}{|c|c|}
\hline Author(s) & Variables \\
\hline Chebat, Davidow, and & Learning Costs, Continuity Costs, Contractual Costs, Search \\
\hline Borges (2011) & Costs, Sunk Costs, Setup Costs \\
\hline Burnham, Frels, and & Economic Risk Costs, Evaluation Costs, Learning Costs, Setup \\
\hline Mahajan (2003) & $\begin{array}{l}\text { Costs, Benefit Loss Cost, Monetary Loss Costs, Personal } \\
\text { Relationship Loss Costs }\end{array}$ \\
\hline Hsu (2014) & Uncertainty Cost, Loss Cost, Sunk Cost, Transition Cost \\
\hline Shin and Kim (2008) & Switching Barriers and Switching Cost \\
\hline Barroso and Picón (2012) & $\begin{array}{l}\text { Benefit Loss Losts, Personal Relationship Loss Costs, Economic } \\
\text { Risk Costs, Evaluation Costs, Set-Up Costs, Monetary Loss Costs }\end{array}$ \\
\hline Han, Kim, and Hyun (2011) & Monetary Switching Costs and Non-Monetary Switching Costs, \\
\hline $\begin{array}{l}\text { Chiu, Hsieh, Li, and Lee } \\
\text { (2005) }\end{array}$ & Financial Bonds, Social Bonds, Structural Bonds \\
\hline $\begin{array}{l}\text { Paul G. Patterson and Smith } \\
(2003)\end{array}$ & $\begin{array}{l}\text { Search Costs, Need to Explain Preferences, Loss of } \\
\text { Interpersonal Relationship }\end{array}$ \\
\hline $\begin{array}{l}\text { Augusto de Matos, Luiz } \\
\text { Henrique, and de Rosa } \\
\text { (2013) }\end{array}$ & Switching Cost \\
\hline $\begin{array}{l}\text { M. A. Jones, Mothersbaugh, } \\
\text { and Beatty (2002) }\end{array}$ & $\begin{array}{l}\text { Pre-Switching Search and Evaluation Costs, Costs of Lost } \\
\text { Performance, Uncertainty Costs, Post-Switching Behavioral and } \\
\text { Cognitive Costs, Sunk Costs, Setup Costs }\end{array}$ \\
\hline
\end{tabular}

\subsection{Independent Varibles}

\subsubsection{Costs of Lost Performance}

When a customer is on the verge of a switching service provider decision, there may exist some amount of perceived risk or uncertainty that the new service provider may lack performance. Costs of lost performance are operationalized as continuity costs (Chebat et al., 2011), economic risk costs (Burnham et al., 2003), risk perceptions (Paul G. Patterson and Smith, 2003), costs of lost performance and uncertainty costs (M. A. Jones et al., 2002) in the literature.

\subsubsection{Learning Costs}

In service context, most of the learning costs are service provider-specific. An adaptation period with the new service provider is required. Learning costs are the time and effort costs in order to get used to new service provider and new service delivery system. Authors have operationalized learning costs as post-switching behavioral and cognitive costs (M. A. Jones et al., 2002), need to explain preferences (Paul G. Patterson and Smith, 2003), learning costs (Burnham et al., 2003; Chebat et al., 2011).

\subsubsection{Sunk Costs}

Sunk costs are customer perceptions of loss of invested time, money, and effort in consumer provider relationship, which are supposed to become sunk cost after switching the bank. Increasing sunk cost is a widely used switching barrier strategy in service sector. These costs mostly include limited to loss of loyalty reward program benefits, but also psychological or social costs. Authors operationalized sunk costs as sunk costs (Chebat et al., 2011; M. A. Jones et al., 2002), monetary, non-monetary and relational investment (Han et al., 2011), benefit loss costs (Barroso and Picón, 2012; Burnham et al., 2003) and switching cost loss (Hsu, 2014).

\subsubsection{Setup Cost/Switching Cost}

Setup costs refer to the time, money and effort needed to establish a new relationship with the new service providers. They can be monetary or non-monetary which can include setup costs 
(Barroso and Picón, 2012; Burnham et al., 2003; Chebat et al., 2011; M. A. Jones et al., 2002), switching cost (Augusto de Matos et al., 2013), economic risk costs (Barroso and Picón, 2012; Burnham et al., 2003), monetary loss costs (Barroso and Picón, 2012), switching cost-uncertainty, switching cost-sunk, switching cost-transition (Hsu, 2014).

\subsubsection{Special Treatment Benefits}

Special treatment benefits are, preferential treatment and special favors as a result of a longterm friendly relationship between the consumer and the service provider (Patterson and Smith 2003), which the consumer may lose in case of switching.

\subsubsection{Financial Bonds}

Financial bonds (Chiu et al., 2005) or contractual costs (Chebat et al., 2011) are service providers effort to build a financial barrier against consumer switching behavior. Generally, financial bonds are used as a part of loyalty reward program as a motivation for the consumer to maintain a longterm relationship to save money (Gwinner, Gremler et al. 1998, Peltier and Westfall 2000). Loyal customers are rewarded with discount price offers, point accumulations, gifts, long-term contract discounts etc., which consumer may lose in case of switching.

\subsubsection{Social Bonds}

Social bonds (Chiu et al., 2005) or personal relationship loss costs (Barroso and Picón, 2012; Burnham et al., 2003) are established through staying in touch with the consumers, learning their needs, and maintaining a positive relationship with them through interpersonal interactions and friendships. Service providers that build social bonds enjoy benefits of understanding, openness and closeness with their customers, which the alternative service provider may lack.

\subsubsection{Structural Bonds}

In this paper structural bonds (Chiu et al., 2005) is operationalized as on-going contracts and agreements between the service provider and the consumer, that, when switching the service provider consumer faces some kind of penalty. Structural bonds are supposed to raise loyalty because they rise the customer's switching cost to another service provider.

\subsection{Dependent Variables}

\subsubsection{Involvement}

Involvement is about personal significance and importance given to the service provider and provided services, consumer interest or perception of needs and values, the psychological state that motivates people to be more aware and careful about the service providers, the perceived interest and importance that a consumer attaches to the switching the service provider (Barroso and Picón, 2012; Te'eni-Harari, Lehman-Wilzig, and Lampert, 2009).

\subsubsection{Propensity for Switching}

Propensity for switching is being "keen to change" (Ganesh, Arnold, and Reynolds, 2000) and therefore refers to the degree of tendency to switch between service providers without any apparent motivation. Prone to switching service provider customers switch between alternative service providers, and they are open to new experiences and enjoy trying out new service providers (Juntunen, Grant, and Juga, 2010; Vázquez-Carrasco and Foxall, 2006). Because these consumers lack loyalty, propensity for switching is not directly in relation with the barriers but rather it is moderated by involvement.

\subsubsection{Satisfaction}

Satisfaction with the service provider is widely researched area. Some researchers claim that satisfied consumers develop intention to continue current service (Oliver, 1993; Oliver and Swan, 1989; Ranaweera, 2007; Suh and Youjae, 2006; Wu, DeSarbo, Chen, and Fu, 2006), whereas some 
researchers claim that satisfied consumers may also switch service providers ( $T$. O. Jones and Sasser Jr, 1995; Jung and Yoon, 2012; Ngobo, 1999; Park and Jang, 2014; Stauss and Neuhaus, 1997). More or less, satisfaction is considered one of the critical variables in consumer switching behavior.

\subsubsection{Intention to Stay Loyal}

Intention to stay loyal captures the degree of consumer intentions whether consumer stays loyal or may switch the service provider in the near future (Shin and Kim 2008, Barroso and Picón 2012, Hsu 2014). Switching intentions is measured attitudinally, that actual consumer switching behavior is not measured but consumers' declaration.

\section{Methodology}

Firstly, an organization is chosen deliberately on the verge of making an agreement with a bank of which employee salaries have to be paid using the bank. The organization had been working with the same bank for the last 9 years. The organization has signed an agreement with a new bank. The research was conducted two months later the new bid.

\subsection{Sample}

The universe of the research is the employees of the organization which consists of 953 employees. All universe population is targeted and interviewed. However, due to the resistance of the personnel not participating into study, the total number of 225 questionnaires were collected. Nevertheless, due to missing values 212 ones are ready to be used.

\subsection{Measures and Data}

Data is collected using 5 point Likert type questionnaire ( $1=$ Strongly Disagree, $5=$ Strongly Agree). Items are adopted according to the researches aims based on previous studies; Costs of lost performance and Sunk costs (Jones, Mothersbaugh et al. 2002), Setup Costs/Switching cost (Jones, Mothersbaugh et al. 2000, Chebat, Davidow et al. 2011, Augusto de Matos, Luiz Henrique et al. 2013), Special treatment benefits (Patterson and Smith 2003), Financial bonds, Social bonds, Structural bonds (Chiu, Hsieh et al. 2005), Involvement (Barroso and Picón, 2012), Propensity for switching (Hsu, 2014; Shin and Kim, 2008), Satisfaction (Shin and Kim 2008, Han, Kim et al. 2011, Augusto de Matos, Luiz Henrique et al. 2013, Hsu 2014), Intention to stay loyal (Shin and Kim 2008, Barroso and Picón 2012, Hsu 2014).

The cope of the study does not cover the demographic attributes as no demogrephic variables are not embedded in the model (Billiot and Rodriguez, 2012). Therefor, there is no need to refere to personel attributes. No demographics is asked in order to ensure confidentiality.

\subsection{Hypothesis Development}

In the proposed conceptual model costs of lost performance, learning costs, sunk costs, setup cost/switching cost, special treatment benefits, financial bonds, social bonds, structural bonds are independent variables, involvement, propensity for switching, satisfaction, intention to stay loyal are the dependent variables.

\subsubsection{Switching Barriers, Involvement and Satisfaction Relationship}

Involvement refers to the degree of concern for, or interest in, the purchase process; in particular the cost, effort, or investment in a purchase (Homburg and Giering, 2001; Richins and Bloch, 1986). It is shown that involvement influences the switching behaviour, satisfaction and loyalty relationship (Balabanis, Reynolds, and Simintiras, 2006). Dagger and David (2012) supports a detailed literature review on switching barriers, involvement and satisfaction relationship.

\subsubsection{Satisfaction, Propensity for Switching and Loyalty Relationship}


Satisfaction is one of the most used variable in explaining loyalty. Authors operationalized satisfaction and continuity (Selnes, 1998), satisfaction and behavioural intentions (Brady and Robertson, 2001; Olorunniwo, Hsu, and Udo, 2006), satisfaction and repurchase intention (Caruana, 2002; Homburg and Giering, 2001; Paul G Patterson, 2004; Rauyruen and Miller, 2007), satisfaction and retention (Burnham et al., 2003; Gustafsson, Johnson, and Roos, 2005), customer satisfaction and customer loyalty (Yang and Peterson, 2004), satisfaction and loyalty (Lam, Shankar, Erramilli, and Murthy, 2004), satisfaction, intention to continue with the current service provider and switching behaviors is operationalized in their model by the researchers (Barroso and Picón, 2012, p.536; Paul G. Patterson and Smith, 2003).

\subsubsection{Conceptual Model}

In Structural Equation Modeling (SEM), every one headed arrow suggests a regression equation. In SEM, conceptually proposed model is tested. In other words, the fit between conceptually proposed model and data collected is researched. An important advantage of SEM studies is that it offers testing of alternative models. Although considered as an independent variable at first, alternative model testing strategies suggested (according to better goodness of fit indices) Involvement is a variable between CSB variables and propensity for switching and satisfaction variables. Thus, in the conceptual model it is hypothesized that intention to stay loyal (or switch) is effected by consumer satisfaction and propensity for switching variables, which are effected by involvement and involvement is effected by switching barriers. The proposed conceptual model means consumer switching barriers have effect if only they are given importance by the consumers (captured by involvement variable).

Figure 1: Conceptual model

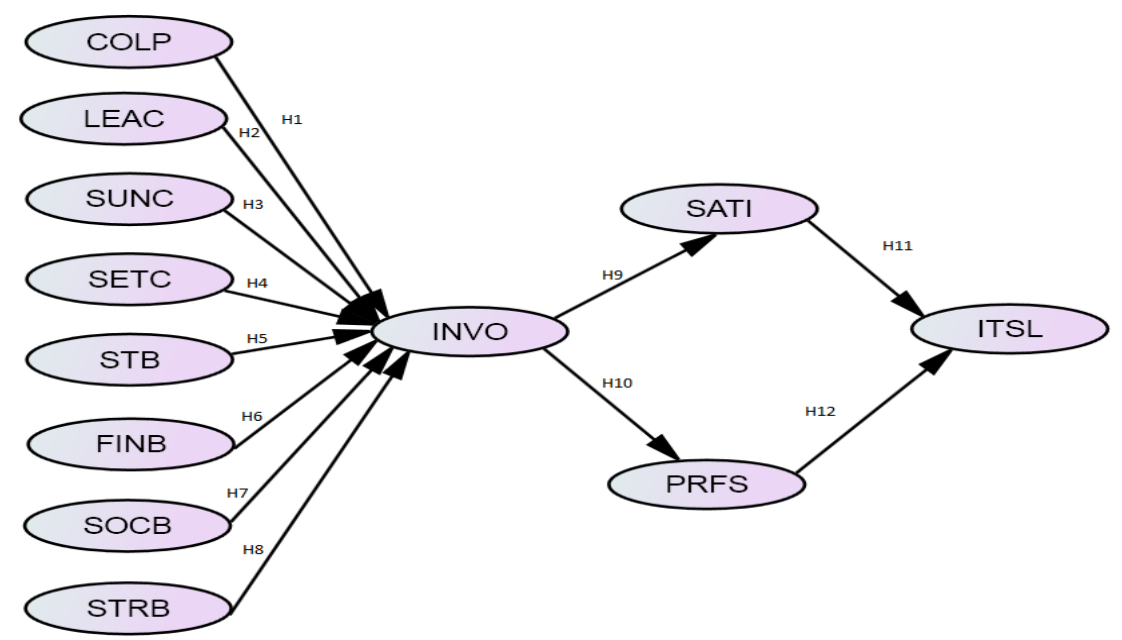

$* *$ Costs of lost performance $=$ COLP, Learning Costs $=$ LEAC, Sunk costs $=$ SUNC, Setup cost $/$ Switching cost $=$ SETC, Special treatment benefits $=S T B$, Financial bonds = FINB, Social bonds= SOCB, Structural bonds= STRB, Involvement= INVO, Propensity for Switching= PRFS, Satisfaction = SATI, Intention to stay loyal= ITSL

Thus; represented by every arrow, in the conceptual model, hypothesys of the study are;

$\mathrm{H}_{1}$ : Costs of lost performance have effect on involvement.

$\mathrm{H}_{2}$ : Learning costs have effect on involvement.

$\mathrm{H}_{3}$ : Sunk costs have effect on involvement.

$\mathrm{H}_{4}$ : Setup/Switching costs have effect on involvement.

$\mathrm{H}_{5}$ : Special treatment benefits have effect on involvement. 
$\mathrm{H}_{6}$ : Financial bonds have effect on involvement.

$\mathrm{H}_{7}$ : Social bonds have effect on involvement.

$\mathrm{H}_{8}$ : Structural bonds have effect on involvement.

$\mathrm{H}_{9}$ : Involvement have effect on satisfaction.

$\mathrm{H}_{10}$ : Involvement have effect on propensity for switching.

$H_{11}$ : Satisfaction have effect on intention to stay loyal.

$\mathrm{H}_{12}$ : Propensity for Switching have effect on intention to stay loyal.

Although, 12 hypotheses can be derived from the conceptual model, the aim of the study is not to test each hypothesis one by one, but the model as a whole which is the advantage of SEM over regression (Cheng, 2001; Jöreskog, 1993). Structural equations modelling technology allows models to be fit to covariance data (Barrett, 2007, p.817). Goodness of fit indices are calculated for the model fit and suggest the fit of the model as a whole.

\subsection{Confirmatory Factor Analysis (CFA)}

In order to test the reliability of the observed variables confirmatory factor analysis (CFA) is conducted. The conceptual model proposes 12 latent variables (Figure 1).

The fit indices indicate a good fit of the data to the hypothesized structure $\left(x^{2} / d f=1,9594\right.$, RMSEA=0.067, CFI=0.97, NNFI (TLI)=0.97) (Schreiber, 2008) and all items loaded statistically significantly $(P<.05)$, however, two items (PRFS4 4_I would switch my bank only when I would not encounter any problem and, ITSL I would have been thinking working with a new bank.) are removed due to low loadings. Composite reliability (CR) and average variance extracted (AVE) calculated for latent variables (Table 2 ) are higher than 0,50 representing adequate values.

Table 2: Construct Reliability (CR) and Average Variance Extracted (AVE) values for CFA

\begin{tabular}{lll}
\hline & CR & AVE \\
\hline Costs of lost performance & 0,740088106 & 0,706058191 \\
Learning costs & 0,592696629 & 0,509156765 \\
Sunk costs & 0,661849711 & 0,60912705 \\
Setup cost/Switching cost & 0,624531835 & 0,554310738 \\
Special treatment benefits & 0,676724138 & 0,625187406 \\
Financial bonds & 0,735294118 & 0,698855651 \\
Social bonds & 0,629055007 & 0,560656176 \\
Structural bonds & 0,704347826 & 0,659375522 \\
Involvement & 0,817073171 & 0,799612584 \\
Propensity for switching & 0,605042017 & 0,53078203 \\
Satisfaction & 0,997992864 & 0,997794253 \\
Intention to stay loyal & 0,648725212 & 0,586515056 \\
\hline
\end{tabular}

Table 3: Goodness of Fit Indices for Confirmatory Factor Analysis

\begin{tabular}{ll}
\hline $\mathrm{x}^{2} / \mathrm{df}$ & 1,9594 \\
RMSEA & 0.067 \\
CFI & 0.97 \\
NNFI (TLI) & 0.97 \\
\hline
\end{tabular}

\subsection{Data analysis and Results}

Standardized values between observed variables and latent variables are provided in Table 5, and standardized values between latent variables are given in Figure 2 . The fit indices $\left(x^{2} / d f=2,1307\right.$, RMSEA $=0,073, C F I=0,96$ and NNFI $\left.(T L I)=0,96\right)$ suggest a good fit (Table 4). 
Table 4: Goodness of Fit Indices of the Tested Model

\begin{tabular}{ll}
\hline $\mathrm{x}^{2} / \mathrm{df}$ & 2,1307 \\
RMSEA & 0,073 \\
CFI & 0,96 \\
NNFI (TLI) & 0,96 \\
\hline
\end{tabular}

The path analysis indicates that intention to stay loyal (ITSL) is positively affected by satisfaction (SATI) with the current bank and negatively affected by propensity for switching (PRFS). Results indicate that the higher the satisfaction and the less the consumer's proneness to switch, the consumer resists bank switching.

Figure 2: Path Diagram for the Tested Model

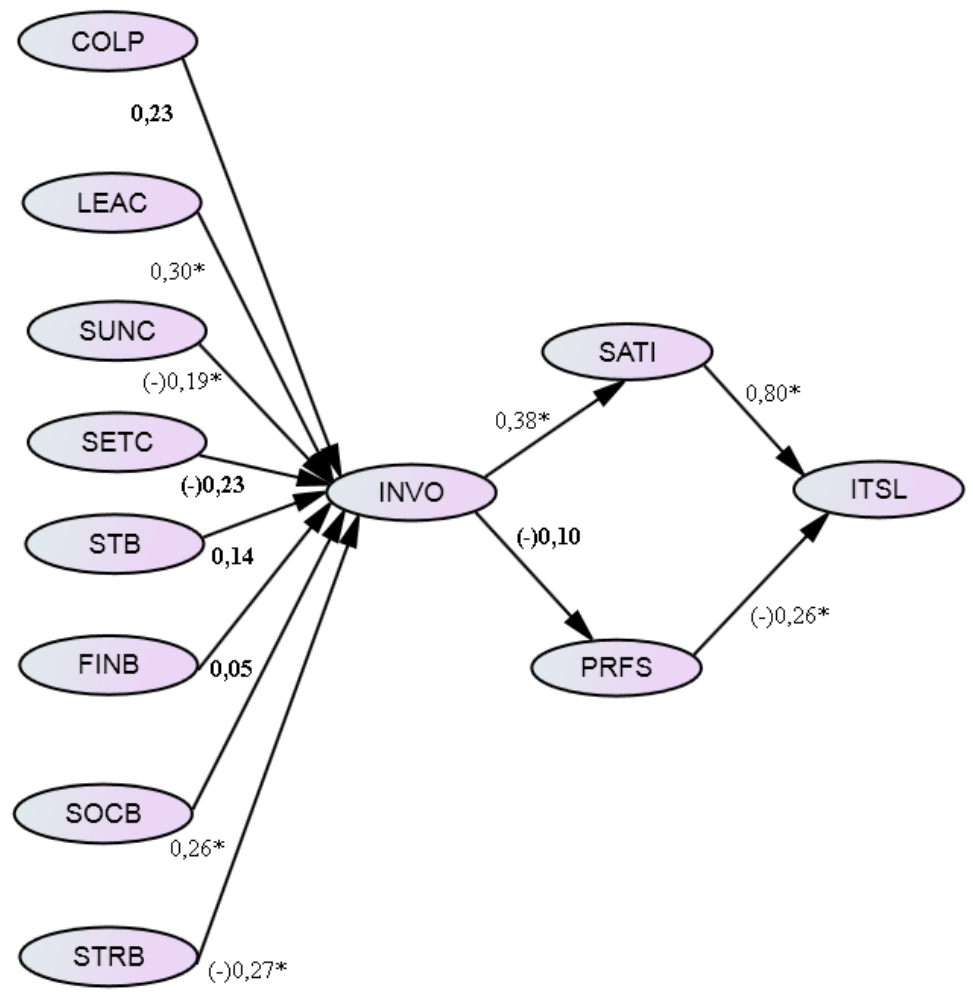

*For values $p<0,05$.

Involvement has a positive significant effect on satisfaction, but no statistically significant effect on PRFS. Although, focus of structural modeling is to estimate relationships among hypothesized latent constructs, structural modeling can be used to test different models (Schreiber, 2008, p. 95), and best model according to fit indices is achieved with involvement between switching barriers and satisfaction. Results are interpreted as switching barriers only have effect if they are given importance by the consumer.

Learning costs (LEAC), sunk costs (SUNC), social bonds (SOCB), structural bonds (STRB) are found to have a significant effect on involvement, but Costs of lost performance (COLP), setup cost/switching cost (SETC), special treatment benefits (STB), financial bonds (FINB) do not have a statistically significant effect on involvement. The results suggest that learning costs and social bond have a positive, where sunk costs and structural bond have a negative effect on involvement. 
Table 5: Standardized Path Coefficients of the Tested Model*

\begin{tabular}{|c|c|c|c|c|c|c|c|c|c|c|c|c|}
\hline & $\begin{array}{l}\mathrm{COL} \\
\mathrm{P}\end{array}$ & $\begin{array}{l}\text { LEA } \\
\text { C }\end{array}$ & $\begin{array}{l}\text { SUN } \\
\text { C }\end{array}$ & $\begin{array}{l}\text { SET } \\
\text { C }\end{array}$ & STB & $\begin{array}{l}\text { FIN } \\
B\end{array}$ & $\begin{array}{l}\text { SOC } \\
\text { B }\end{array}$ & $\begin{array}{l}\text { STR } \\
\text { B }\end{array}$ & $\begin{array}{l}\text { INV } \\
0\end{array}$ & $\begin{array}{l}\text { PRF } \\
S\end{array}$ & $\begin{array}{l}\text { SAT } \\
\text { I }\end{array}$ & ITSL \\
\hline COLP1 & 0,85 & & & & & & & & & & & \\
\hline COLP2 & 0,78 & & & & & & & & & & & \\
\hline COLP3 & 0,92 & & & & & & & & & & & \\
\hline COLP4 & 0,80 & & & & & & & & & & & \\
\hline LEAC1 & & 0,80 & & & & & & & & & & \\
\hline LEAC2 & & 0,63 & & & & & & & & & & \\
\hline LEAC3 & & 0,71 & & & & & & & & & & \\
\hline SUNC & & & 0,89 & & & & & & & & & \\
\hline 1 & & & 0,87 & & & & & & & & & \\
\hline SUNC & & & 0,54 & & & & & & & & & \\
\hline 2 & & & & & & & & & & & & \\
\hline SUNC & & & & & & & & & & & & \\
\hline 3 & & & & & & & & & & & & \\
\hline SETC1 & & & & 0,79 & & & & & & & & \\
\hline SETC2 & & & & 0,78 & & & & & & & & \\
\hline SETC3 & & & & 0,69 & & & & & & & & \\
\hline SETC4 & & & & 0,58 & & & & & & & & \\
\hline SETC5 & & & & 0,74 & & & & & & & & \\
\hline SETC6 & & & & 0,84 & & & & & & & & \\
\hline SETC7 & & & & 0,77 & & & & & & & & \\
\hline SETC8 & & & & 0,74 & & & & & & & & \\
\hline SETC9 & & & & 0,73 & & & & & & & & \\
\hline STB1 & & & & & 0,6 & & & & & & & \\
\hline STB2 & & & & & 4 & & & & & & & \\
\hline STB3 & & & & & 0,8 & & & & & & & \\
\hline \multirow[t]{5}{*}{ STB4 } & & & & & 0 & & & & & & & \\
\hline & & & & & 0,8 & & & & & & & \\
\hline & & & & & 9 & & & & & & & \\
\hline & & & & & 0,8 & & & & & & & \\
\hline & & & & & 2 & & & & & & & \\
\hline FINB1 & & & & & & 0,82 & & & & & & \\
\hline FINB2 & & & & & & 0,80 & & & & & & \\
\hline FINB3 & & & & & & 0,89 & & & & & & \\
\hline SOCB & & & & & & & 0,79 & & & & & \\
\hline 1 & & & & & & & 0,84 & & & & & \\
\hline SOCB & & & & & & & 0,82 & & & & & \\
\hline 2 & & & & & & & 0,65 & & & & & \\
\hline SOCB & & & & & & & 0,65 & & & & & \\
\hline 3 & & & & & & & 0,74 & & & & & \\
\hline \multicolumn{13}{|l|}{ SOCB } \\
\hline \multicolumn{13}{|l|}{4} \\
\hline \multicolumn{13}{|l|}{ SOCB } \\
\hline \multicolumn{13}{|l|}{5} \\
\hline \multicolumn{13}{|l|}{ SOCB } \\
\hline 6 & & & & & & & & & & & & \\
\hline
\end{tabular}




\begin{tabular}{|c|c|c|c|c|c|}
\hline STRB1 & 0,74 & & & & \\
\hline STRB2 & 0,84 & & & & \\
\hline STRB3 & 0,81 & & & & \\
\hline STRB4 & 0,86 & & & & \\
\hline STRB5 & 0,86 & & & & \\
\hline STRB6 & 0,75 & & & & \\
\hline INVO1 & & 0,96 & & & \\
\hline INVO2 & & 0,82 & & & \\
\hline PRFS1 & & & 0,73 & & \\
\hline PRFS2 & & & 0,89 & & \\
\hline PRFS3 & & & 0,53 & & \\
\hline SATI1 & & & & 0,8 & \\
\hline SATI2 & & & & 9 & \\
\hline \multirow[t]{4}{*}{ SATI3 } & & & & 0,8 & \\
\hline & & & & 9 & \\
\hline & & & & 0,9 & \\
\hline & & & & 0 & \\
\hline ITSL1 & & & & & 0,8 \\
\hline ITSL2 & & & & & 4 \\
\hline \multirow[t]{4}{*}{ ITSL3 } & & & & & 0,7 \\
\hline & & & & & 6 \\
\hline & & & & & 0,6 \\
\hline & & & & & 4 \\
\hline
\end{tabular}

*For all coefficients $p<0,05$.

\section{Discussion}

The aim of the study is to test the conceptual relationships between switching barriers and intention to switch based on a real life case. Literature supports evidence for such a relationship. In this paper, consumers' intention to switch or stay loyal behavior is researched in an extraordinary situation that a bank offers cash in order to convince consumers to switch their current bank, thus, an opportunity to study the switching barriers effect on intention to stay loyal or switch the bank arises. The study operationalized structural equation modeling to determine the best conceptual model that fits observed data. Previous researchers operationalized switching barriers as a mediator (Lee et al., 2001; Yang and Peterson, 2004) or as an independent variable to explain loyalty (e.g. Kim et al., 2004; Lam et al., 2004). In this paper switching barriers are operationalized as independent variables, and involvement, satisfaction and propensity to switch as mediators. Results suggest that switching barriers indirectly affect consumer's intentions to stay loyal over involvement and satisfaction, and propensity to switch behavior is an independent variable, and not all switching barriers have significant effect.

The banks as service providers in general establish switching barriers. Results of the study suggest that consumers consider the time and effort costs in order to get used to new service provider and new service delivery system; loss of invested time, money, and effort in consumer provider relationship; the positive relationship with the service provider; and, on-going contracts and agreements between the service provider and the consumer.

Customers' perceived performance risk or uncertainty; the time, money and effort needed to establish a new relationship with the new service provider; preferential treatment and special favors; and financial barriers against consumer switching behavior are found to have no effect on intention to stay loyal.

The paper's contribution to theory is that a new promotion strategy to attract new customers by providing free pre-defined services and amount of cash might be an effective method whether 
customers see those benefits attractive to change their bank to work with. On the other hand, whether some switching barriers posed by the bank or accustomed services detaining customers not to switch into new bank have existed or not. The study shows that intention to stay loyal is influenced by satisfaction with the current bank, which to some degree under the banks control, and propensity to switch which is consumer specific. Statistically significant switching barriers are moderated by involvement. They work only if they are given importance by the consumers. This relationship was unforeseen, although it is congruent with the literature and the logic.

In practice, firms try to grow by acquiring competitors' customers in saturated markets like banking sector. This study suggests that consumers may not be bought, but earned with establishing and maintaining a relationship. The only economical switching barrier useful for consumer's intention to stay loyal is found to be long-term contracts and agreements, which is also stated in the literature. Also, customers that are acquired may be those that are the most difficult to retain (Matzler, Strobl, Thurner, and Füller, 2015).

As the entire banking sector relies heavily on similar information technologies, it is interpreted that performance loss risk is found to have no significant effect on consumer switching in banking sector. Technology also reduces the effect of set-up costs where online banking makes everything one-click-away. It can be proposed that technological development in banking sector made registering a customer faster and easier, as a result switching become easier with the technology. Furthermore, point accumulation is found to have no effect on intention to stay loyal, because every bank has a loyalty program and accumulated points can be spend before switching, loyalty reward programs may not be a strategic tool anymore. The interesting finding is that consumer intention to stay loyal is not effected by special treatment benefits, it may be the result of nonexistence of special treatments, or may be because of the perception that it would not differ to a great extent between banks. In more high-contact service sectors, special treatment benefits may have an effect on switching intentions, but this studies results suggest that it does not happen in banking sector. The findings of this study can be interpreted as tools that every bank can offer does not influence consumers' intention to switch or stay loyal, and they should not be considered as strategic efforts. Switching barriers work, if they are inimitable.

The papers findings should be interpreted under limitations. First, the data is collected twomonth after a unique promotion strategy and results may be different under different circumstances. Second, employees resisted answering the questionnaires so the results reflect the perceptions of the respondents only. Also this study depends on only one bank and one organization. The surveys are administered to 212 employees of an organization who compulsorily become consumers of a certain bank, which is another limitation. Future studies may deal with more service providers and organizations at the same time. Lastly, loyalty is measured attitudinally, other types of measurements such as behavioral loyalty needs to be considered as well in future studies.

\section{References}

Augusto de Matos, C., Luiz Henrique, J., and de Rosa, F. (2013). Customer Reactions to Service Failure and Recovery in the Banking Industry: The Influence of Switching Costs. Journal of Services Marketing, 27(7), 526-538.

Balabanis, G., Reynolds, N., and Simintiras, A. (2006). Bases of E-store Loyalty: Perceived Switching Barriers and Satisfaction. Journal of Business Research, 59(2), 214-224.

Barrett, P. (2007). Structural Equation Modelling: Adjudging Model Fit. Personality and Individual Differences, 42(5), 815-824.

Barroso, C., and Picón, A. (2012). Multi-Dimensional Analysis of Perceived Switching Costs. Industrial Marketing Management, 41(3), 531-543. 
Billiot, T., and Rodriguez, A. (2012). Cultivating Consumer Relationships Through Hypertext and Hypermedia Websites. Journal of Relationship Marketing, 11(2), 72-90.

Brady, M. K., and Robertson, C. J. (2001). Searching for a Consensus on the Antecedent Role of Service Quality and Satisfaction: An Exploratory Cross-National Study. Journal of Business Research, 51(1), 53-60.

Burnham, T. A., Frels, J. K., and Mahajan, V. (2003). Consumer Switching Costs: A Typology, Antecedents, and Consequences. Journal of the Academy of Marketing Science, 31(2), 109-126.

Caruana, A. (2002). Service Loyalty: The Effects of Service Quality and the Mediating Role of Customer Satisfaction. European Journal of Marketing, 36(7/8), 811-828.

Chebat, J.-C., Davidow, M., and Borges, A. (2011). More on the Role of Switching Costs in Service Markets: A Research Note. Journal of Business Research, 64(8), 823-829.

Cheng, E. W. (2001). SEM Being More Effective Than Multiple Regression in Parsimonious Model Testing for Management Development Research. Journal of Management Development, 20(7), 650-667.

Chiu, H.C., Hsieh, Y.C., Li, Y.C., and Lee, M. (2005). Relationship Marketing and Consumer Switching Behavior. Journal of Business Research, 58(12), 1681-1689.

Dagger, T. S., and David, M. E. (2012). Uncovering the Real Effect of Switching Costs on the Satisfaction-Loyalty Association: The Critical Role of Involvement and Relationship Benefits. European Journal of Marketing, 46(3/4), 447-468.

Ehrenberg, A. S., Goodhardt, G. J., and Barwise, T. P. (1990). Double Jeopardy Revisited. The Journal of Marketing, 82-91.

Ganesh, J., Arnold, M. J., and Reynolds, K. E. (2000). Understanding the Customer Base of Service Providers: An Examination of the Differences Between Switchers and Stayers. Journal of Marketing, 64(3), 65-87.

Gustafsson, A., Johnson, M. D., and Roos, I. (2005). The Effects of Customer Satisfaction, Relationship Commitment Dimensions, and Triggers on Customer Retention. Journal of Marketing, 69(4), 210-218.

Han, H., Kim, W., and Hyun, S. S. (2011). Switching Intention Model Development: Role of Service Performances, Customer Satisfaction, and Switching Barriers in the Hotel industry. International Journal of Hospitality Management, 30(3), 619-629.

Homburg, C., and Giering, A. (2001). Personal Characteristics as Moderators of the Relationship Between Customer Satisfaction and Loyalty-An Empirical Analysis. Psychology and Marketing, 18(1), 43-66.

Hsu, J. S.C. (2014). Understanding the Role of Satisfaction in the Formation of Perceived Switching Value. Decision Support Systems, 59, 152-162.

Jones, M. A., Mothersbaugh, D. L., and Beatty, S. E. (2002). Why Customers Stay: Measuring the Underlying Dimensions of Services Switching Costs and Managing Their Differential Strategic Outcomes. Journal of Business Research, 55(6), 441-450.

Jones, T. O., and Sasser Jr, W. E. (1995). Why Satisfied Customers Defect. Harvard Business Review, 73(6), 88-91.

Jöreskog, K. G. (1993). Testing Structural Equation Models. Sage Focus Editions, 154, 294-294. 
Jung, H. S., and Yoon, H. H. (2012). Why do Satisfied Customers Switch? Focus on the Restaurant Patron Variety-Seeking Orientation and Purchase Decision Involvement. International Journal of Hospitality Management, 31(3), 875-884.

Juntunen, J., Grant, D. B., and Juga, J. (2010). Short-Run ss Long-Run Trade-Offs in Outsourcing Relationships: Impacts on Loyalty and Switching Propensity. Strategic Outsourcing: An International Journal, 3(3), 211-225.

Lam, S. Y., Shankar, V., Erramilli, M. K., and Murthy, B. (2004). Customer Value, Satisfaction, Loyalty, and Switching Costs: An Illustration From a Business-to-Business Service Context. Journal of the Academy of Marketing Science, 32(3), 293-311.

Matzler, K., Strobl, A., Thurner, N., and Füller, J. (2015). Switching Experience, Customer Satisfaction, and Switching Costs in the ICT Industry. Journal of Service Management, 26(1), 117-136.

Ngobo, P.V. (1999). Decreasing Returns in Customer Loyalty: Does It Really Matter to Delight the Customers? Advances in Consumer Research, 26, 469-476.

Oliver, R. L. (1993). Cognitive, Affective, and Attribute Bases of the Satisfaction Response. Journal of Consumer Research, 418-430.

Oliver, R. L., and Swan, J. E. (1989). Consumer Perceptions of Interpersonal Equity and Satisfaction in Transactions: A Field Survey Approach. The Journal of Marketing, 21-35.

Olorunniwo, F., Hsu, M. K., and Udo, G. J. (2006). Service Quality, Customer Satisfaction, and Behavioral Intentions in the Service Factory. Journal of Services Marketing, 20(1), 59-72.

Park, J.Y., and Jang, S. S. (2014). Why Do Customers Switch? More Satiated or Less Satisfied. International Journal of Hospitality Management, 37, 159-170.

Patterson, P. G. (2004). A Contingency Model of Behavioural Intentions in a Services Context. European Journal of Marketing, 38(9/10), 1304-1315.

Patterson, P. G., and Smith, T. (2003). A Cross-Cultural Study of Switching Barriers and Propensity to Stay with Service Providers. Journal of Retailing, 79(2), 107-120.

Ranaweera, C. (2007). Are Satisfied Long-Term Customers More Profitable? Evidence From the Telecommunication Sector. Journal of Targeting, Measurement and Analysis for Marketing, 15(2), 113-120.

Rauyruen, P., and Miller, K. E. (2007). Relationship Quality as A Predictor of B2B Customer Loyalty. Journal of Business Research, 60(1), 21-31.

Richins, M. L., and Bloch, P. H. (1986). After the New Wears Off: The Temporal Context of Product Involvement. Journal of consumer research, 13(2), 280-285.

Schreiber, J. B. (2008). Core Reporting Practices in Structural Equation Modeling. Res Social Adm Pharm, 4(2), 83-97.

Selnes, F. (1998). Antecedents and Consequences of Trust and Satisfaction in Buyer-Seller Relationships. European Journal of Marketing, 32(3/4), 305-322.

Shin, D.H., and Kim, W.Y. (2008). Forecasting Customer Switching Intention in Mobile Service: An Exploratory Study of Predictive Factors in Mobile Number Portability. Technological Forecasting and Social Change, 75(6), 854-874.

Stauss, B., and Neuhaus, P. (1997). The Dissatisfaction Potential of Satisfied Customers-The Qualitative Satisfaction Model-. In Advances in Services Marketing (pp. 111-131): Springer. 
Suh, J.C., and Youjae, Y. (2006). When Brand Attitudes Affect the Customer Satisfaction-Loyalty Relation: The Moderating Role of Product Involvement. Journal of Consumer Psychology, 16(2), 145-155.

Te'eni-Harari, T., Lehman-Wilzig, S. N., and Lampert, S. I. (2009). The Importance of Product Involvement for Predicting Advertising Effectiveness Among Young People. International Journal of Advertising, 28(2), 203-229.

Vázquez-Carrasco, R., and Foxall, G. R. (2006). Positive vs. Negative Switching Barriers: The Influence of Service Consumers' Need For Variety. Journal of Consumer Behaviour, 5(4), 367-379.

Wu, J., DeSarbo, W. S., Chen, P.J., and Fu, Y.Y. (2006). A Latent Structure Factor Analytic Approach for Customer Satisfaction Measurement. Marketing Letters, 17(3), 221-238.

Yang, Z., and Peterson, R. T. (2004). Customer Perceived Value, Satisfaction, and Loyalty: The Role of Switching Costs. Psychology and Marketing, 21(10), 799-822. 
